Cystic fibrosis (CF) lung disease is characterized by persistent inflammation. Antiinflammatory drugs, such as corticosteroids and ibuprofene, have proved to slow the decline of pulmonary function although their use is limited because of frequent adverse events. We hypothesized that colchicine could be an alternative treatment because of its antiinflammatory properties and upregulatory effect on cystic fibrosis transmembrane regulator (CFTR) closely related proteins. We herein present results obtained in an open study of eight $\mathrm{CF}$ children treated with colchicine for at least 6 months. Clinical status was better in all patients and respiratory function tests significantly improved in five. Median duration of antibiotherapy decreased significantly. These preliminary results support our hypothesis of a beneficial effect of colchicine in $C F$ patients and stress the need for a controlled therapeutic trial.

Key words: Cystic Fibrosis, Inflammation, Cystic fibrosis transmembrane regulator, $\mathrm{ABC}$ protein, Colchicine

\section{Interest of colchicine for the treatment of cystic fibrosis patients. Preliminary report}

\author{
I. Sermet-Gaudelus, ${ }^{1}$ V. Stoven, ${ }^{2}$ J.P. Annereau, ${ }^{2}$ \\ V. Witko-Sarsat, ${ }^{3}$ P. Reinert, ${ }^{4}$ M. Guyot, ${ }^{5}$ \\ B. Descamps-Latscha ${ }^{3}$ J.Y. Lallemand ${ }^{2}$ and \\ G. Lenoir ${ }^{1, C A}$
}

${ }^{1}$ Service de Pédiatrie II, Hôpital Necker-Enfants Malades, 149 rue de Sèvres, 75015 Paris;

${ }^{2}$ Laboratoire de Résonnance Magnétique Nucléaire, Ecole Polytechnique, Massy Palaiseau; ${ }^{3}$ INSERM

U507, Hôpital Necker, Paris; ${ }^{4}$ Pediatric Department, Hôpital Intercommunal, Créteil; ${ }^{5}$ Pediatric

Department, Hôpital de Lisieux, France

\author{
${ }^{\mathrm{CA}}$ Corresponding Author \\ Tel: (+33) 144494883 \\ Fax: (+33) 147833226 \\ Email: gérard.lenoir@nck.ap-hop-paris.fr
}

\section{Introduction}

Lung disease in cystic fibrosis (CF) patients is characterized by persistent bacterial infection leading to chronic bronchitis and bronchectiasis. ${ }^{1}$ Vigorous antibiotherapy, clearance of mucus and adequate nutritional support have been the bases of conventional therapy. Recently, attention has been focused on the lung inflammation which not only damages the parenchyma directly but also impairs local defence against pathogens., ${ }^{2,3}$ Blunting the inflammatory response by using antiinflammatory drugs such as corticosteroids or ibuprofen has been proven to slow the decline of pulmonary function, although the high incidence of adverse events outweighs beneficial effect. $^{4,5}$

Colchicine should be considered as an alternative treatment because of its antiinflammatory properties notably by interference with PNN margination, chemotaxis and phagocytosis. ${ }^{6}$ Interestingly, colchicine has also been shown to upregulate the expression of the multi-drug-resistance (MDR) gene. ${ }^{7}$ This gene encodes for the P-glycoprotein or P-gp which belongs to the ATP binding cassette (ABC) protein family and shares remarkable homology with cystic fibrosis transmembrane regulator (CFTR). ${ }^{8}$ In vitro experiments have shown that closely related $\mathrm{ABC}$ proteins can complement each other. ${ }^{9}$ Taken together, these data led us to propose that colchicine might induce complementation of CFTR by P-gp.

Recently, we reported improvement of lung function in a CF patient after antitumoral therapy and suggested that this could be due to the complementation of CFTR. ${ }^{10}$ However the toxicity of these drugs precludes their wide use in CF patients. We herein present preliminary results showing that colchicine may exert a beneficial effect on CF clinical status.

\section{Materials and methods}

\section{Patients}

Eight patients with CF diagnosed according to conventional criteria entered this open study conducted from 1 March 1997 to 31 December $1997 . .^{12}$ All these patients had end-stage CF lung disease or chronic airflow limitation unresponsive to conventional therapy. Colchicine (Houdé, Paris, France) was administered orally ( $1 \mathrm{mg}$ daily), during at least 6 moths without other antiinflammatory treatment (inhaled or oral steroid therapy, nonsteroidal antiinflammatory drugs) or recombinant human DNase. 
The following parameters were considered every 3 months during the duration of the assay, i.e. at least 6 months: body weight (BW) and height (expressed as standard deviation from ideal weight and height for age); respiratory function tests (forced expiratory volume- FEV1, and forced vital capacity-FVC); number of antibiotic courses in relation to respiratory tract infections. Concomitant therapies and adverse clinical events were documented.

\section{Statistics}

Results are presented as median (range) values. The average values in the 6 months before the beginning of treatment were compared with their post-treatment average after completion of at least 6 months of treatment. Statistical analysis was done using Wilcoxon's signed rank test. $P$ value of less than 0.05 was considered significant.

\section{Results}

\section{Patient characteristics}

Eight patients (six boys) were studied. The characteristics of the patients at beginning of treatment are shown in Table 1 . Median age was 13.5 years (range 5-28 years). Six patients were $\Delta$ F508 homozygous. Median FEV1 and FVC were respectively 54\% (range 21-63\%) and 62\% (37-64\%). Patient 7 was a 27-yearold patient with secondary nephropathic amyloidosis. The occurrence of renal failure justified the start of colchicine therapy. Patient 8 was a 13-year-old girl on the lung transplant waiting list because of a dramatic decline of respiratory function and nutritional status (Fig. 1). Patient 2 and patient 8 both also had concomitant long-term azithromycin started 2 years before.
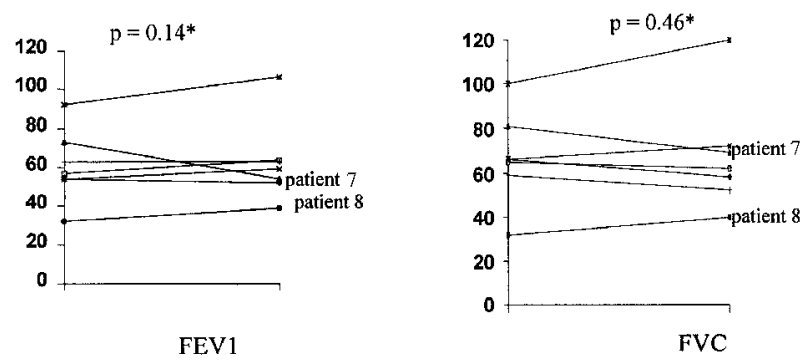

FIG. 1. Evolution of FEV1 and FVC. *Wilcoxon's signed rank test.

\section{Effect of colchicine on patient clinical status}

Median duration of treatment was 7 months (range 6-12 months). No child had change in the baseline treatment during the study period. For all the patients there was a subjective improvement in clinical status. Median duration of antibiotherapy significantly decreased from 5 to 1.2 days per month $(P<0.05)$. Median weight gain was $+0.25 \mathrm{SD}(P=0.1)$.

The respiratory function tests could be performed in seven patients. FEV1 substantially improved in six patients, rising from $54 \%(21-63 \%)$ predicted to $57 \%$ (37-64\%) predicted $(P=0.14)$. In contrast, FVC remained unchanged during the duration of colchicine therapy. Patient 8, on the lung transplant waiting list, had a marked improvement of FEV1 from $21 \%$ to $37 \%$ predicted, and FVC from $32 \%$ to $44 \%$ which prompted his removal from this list. Concomitantly, weight gain ( $4 \mathrm{~kg}$ ) and reduced need for antibiotics (15 days during the 6 months after beginning of treatment versus 30 days during the 6 months before) were observed. The child had recovered good daily activity. It is worth noting that there had been no concomitant change in the usual treatment of this patient.

\section{Adverse effects}

The drug was well tolerated except in two patients who had mild diarrhoea. However, this mild side

Table 1. Baseline characteristics of patients before colchicine treatment

\begin{tabular}{|c|c|c|c|c|c|c|}
\hline Patient (No.) & Age (years) & $\mathrm{BW}^{*}$ & CF mutation & FVC** & $\mathrm{FEV} 1 * *$ & Lung colonization \\
\hline 1 & 10 & -0.5 & DF508/DF508 & $66 \%$ & $54 \%$ & P. aeruginosa \\
\hline 2 & 16 & -1 & DF508/DF508 & $65 \%$ & $60 \%$ & P. aeruginosa Staph. aureus B. Cepacia \\
\hline 3 & 14 & -0.5 & DF508/DF508 & $81 \%$ & $78 \%$ & Staph. aureus \\
\hline 4 & 5 & -1.5 & ? & ND & ND & P. aeruginosa Staph. aureus \\
\hline 5 & 6 & -2 & DF508/DF508 & $66 \%$ & $54 \%$ & H. influenzae \\
\hline 6 & 13 & 0.5 & DF508/DF508 & $90 \%$ & $92 \%$ & $P$. aeruginosa \\
\hline 7 & 28 & -1 & DF508/DF508 & $72 \%$ & $61 \%$ & $P$. aeruginosa \\
\hline 8 & 14 & -2 & DF508/? & $32 \%$ & $32 \%$ & P. aeruginosa B. Cepacia \\
\hline Median & 13.5 & -1 & & 54 & 62 & \\
\hline Range & $5-28$ & $-2-0.5$ & & $21-63$ & $32-68$ & \\
\hline
\end{tabular}

* Expressed as SD for theoretical weight for age;

** Expressed as percentages of theoretical value for age and sex. 
effect did not lead to discontinuation of the treatment.

\section{Discussion}

We report preliminary results showing that colchicine treatment in CF patients is associated with a significant decrease of antibiotherapy, and a potential improvement of respiratory status. To our knowledge, colchicine has not yet been proposed in CF but interestingly, it has already been used for the treatment of idiopathic pulmonary fibrosis ${ }^{12}$ and IgEmediated asthma. ${ }^{13}$

The beneficial effect of colchicine may be due to two different mechanisms: (i) colchicine has antiinflammatory properties due to interference with PNN margination, chemotaxis and phagocytosis ${ }^{14}$ and inhibition of leukotriene synthesis. ${ }^{15}$ It also inhibits fibroblast proliferation and total collagen synthesis; ${ }^{16}$ (ii) colchicine also promotes expression of $\mathrm{ABC}$ proteins such as P-gp which shares great structural homology with CFTR. ${ }^{7,8,17,18}$ Several recent data also suggest functional homology. CFTR overexpression leads to a multidrug-resistance phenotype similar to P-gp. ${ }^{19}$ CFTR exports glutathione and glucuronate anions and may play a role in cell detoxification similar to $\mathrm{MRP}^{20,21}$ As closely related $\mathrm{ABC}$ proteins can complement each other, upregulation of P-gp and/or MRP may hence lead to functional complementation of defective CFTR. ${ }^{9,10}$ This hypothesis is also supported by the expression of MDR in nasal epithelial cells of a CF patient treated with antitumorous drugs but not in a control CF patient who never had chemotherapy. ${ }^{10}$ This function of upregulation of $\mathrm{ABC}$ proteins could be emphasized by the adjunction of other $\mathrm{ABC}$ protein inducers such as azithromycin. ${ }^{22}$ Interestingly, two patients were treated by both drugs and experienced an improvement in clinical status.

In conclusion, colchicine should be considered in the treatment in $\mathrm{CF}$ patients, because of its antiinflammatory role and its property of inducing $\mathrm{ABC}$ proteins. Although preliminary, the potential importance of these results in this severe disease seems to us to justify their early report and has formed the basis of a controlled trial which is now being undertaken by our group.

\section{References}

1. Koch C, Hoiby N. Pathogenesis of cystic fibrosis. Lancet 1993; 341 1065-1069.

2. Khan TZ, Wagener JS, Bost T, et al. Early pulmonary inflammation in infants with cystic fibrosis. Am J Respir Crit Care Med 1995; 151 1075-1082.

3. Descamps-Latscha B, Döring G, Galanaud P, Lenoir G, Navarro J, Schaffar L. Inflammation in Cystic Fibrosis. Med Inflamm 1996; 5: 121-143.

4. Auerbach HS, Williams M, Kirkpatrick JA, Cotten HR. Alternate day prednisolone reduces the morbidity and improves pulmonary function in cystic fibrosis. Lancet 1985 ; ii: 686-688.

5. Konstan MW, Byard PJ, Hoppel CL, Davis PB. Effect of high-dose ibuprofen in patients with cystic fibrosis. N Engl J Med 1995; 331: $848-854$

6. Levy M, Spino M, Read E. Colchicine: a state of the art review. Pharmacother 1991; 11(3): 196-211.

7. Ueda K, Pastan I, Gottesman MM. Isolation and sequence of the promoter region of the human multidrug-resistance (P-glycoprotein) gene. J Biol Chem 1987; 262: 17432-17436.

8. Higgins CF. ABC transporters: from microorganisms to man. Annu Rev Biol 1992; 8: 67-113

9. Tommasini R, Evers R, Vogt E, et al. The human multidrug resistanceassociated protein functionally complements the yeast cadmium resistance factor 1. Proc Natl Acad Sci USA 1996; 93: 6743-6748.

10. Lallemand JY, Stoven V, Annereau JP, Boucher J, Blanquet S, Barthe J, Lenoir $\mathrm{G}$. Induction by antitumoral drugs of proteins that functionally complement CFTR: a novel therapy for cystic fibrosis? Lancet 1997; 350: 711-712.

11. Stern RC. The diagnosis of cystic fibrosis. $N$ Engl J Med 1997; 336 487-491.

12. Douglas WW, Ryu JH, Swensen SJ, et al. Colchicine versus prednisone in the treatment of idiopathic pulmonary fibrosis. Am J Resp Crit Care Med 1998; 158: 220-225.

13. Kelly SJ, Uri AJ, Freeland HS, et al. Effects of colchicine on IgE-mediated early and late airway reactions. Chest 1995; 107: 985-991.

14. Dallaverde E, Fan PT, Chang YH. Mechanism of action of colchicine. V. Neutrophil adherence and phagocytosis in patients with acute gout treated with colchicine. J Pharmacol Exp Ther 1982; 223: 197-202.

15. Peters-Golden M, McNish RW, Davis JA, et al. Colchicine inhibits arachidonate release and 5-lipoxygenase action in alveolar macrophages. Am J Physiol 1996; 271: 6 Pt 1, L1004-1013.

16. Entzian P, Schlaak M, Seitzer U, et al. Antiinflammatory and antifibrotic properties of colchicine: implications for idiopathic pulmonary fibrosis. Lung 1997; 175: 41-51.

17. Vollrath V, Wielandt AM, Acuna C, et al. Effect of colchicine and heat shock on multidrug resistance gene and P-glycoprotein expression in rat liver. J Hepatol 1994; 21: 754-763.

18. Eliseenkova AV, Kakpakova ES, Abdrjashitov RI, Stavrovskaya AA. Colchicine-resistance and enhancment of P-glycoprotein activity after cocultivation of drug-sensitive cells with multidrug resistant variants. Cell Biol Int 1995; 19(2): 113-119.

19. Wei LY, Stutts MJ, Hoffman MM, Roepe PD. Overexpression of the CFTR in NIH 3T3 cells lowers membrane potential and intracellular $\mathrm{pH}$ and confers a multidrug resistance phenotype. Biophys $J$ 1995; 69: $883-895$.

20. Lindsdell P, Hanrahan JW. Glutathione permeability of CFTR. Am J Cell Physiol 1998; 275(44): C323-326.

21. Lindsdell P, Hanrahan JW. Adenosine triphosphate dependant assymetry of anion permeation in cystic fibrosis transmembrane conductance regulator chloride channel. J Gen Physiol 1998; 111: 601-614.

22. Altschuler EL. Azithromycin, the multidrug-resistant protein, and cystic fibrosis. Lancet 1998; 351: 1286.

ACKNOWLEDGEMENT. This work was supported by the association 'ABCF Protéine'.

Received 17 November 1998; accepted in revised form 18 December 1998 


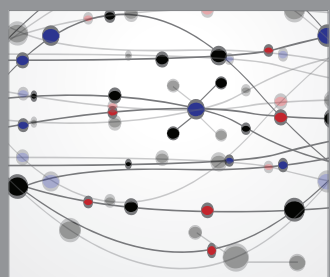

The Scientific World Journal
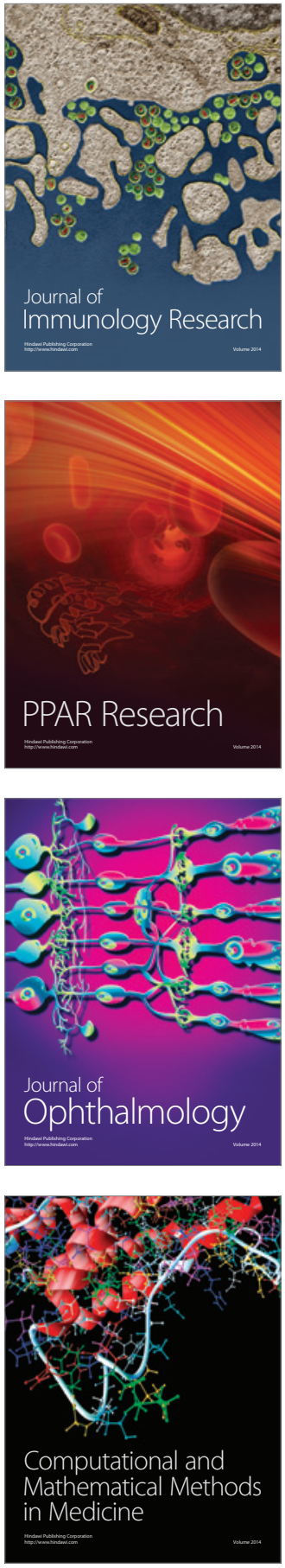

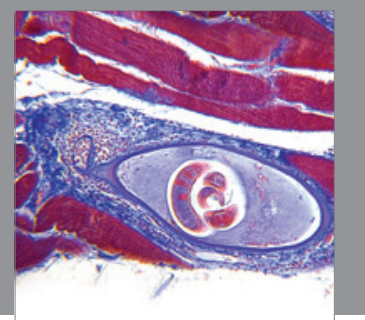

Gastroenterology

Research and Practice
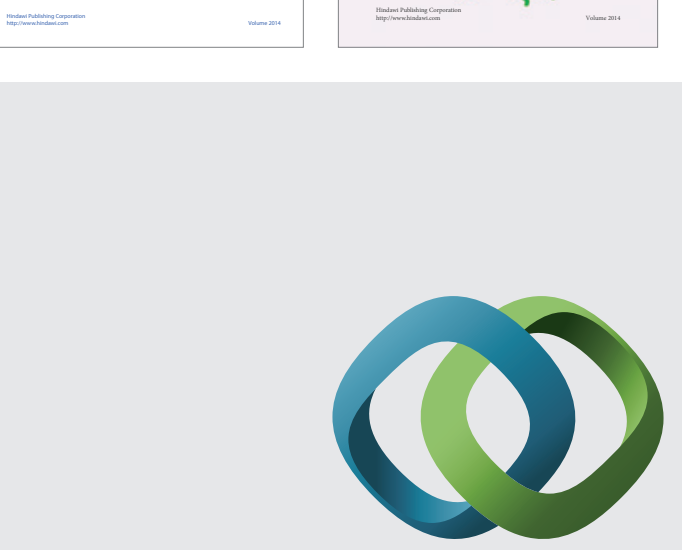

\section{Hindawi}

Submit your manuscripts at

http://www.hindawi.com
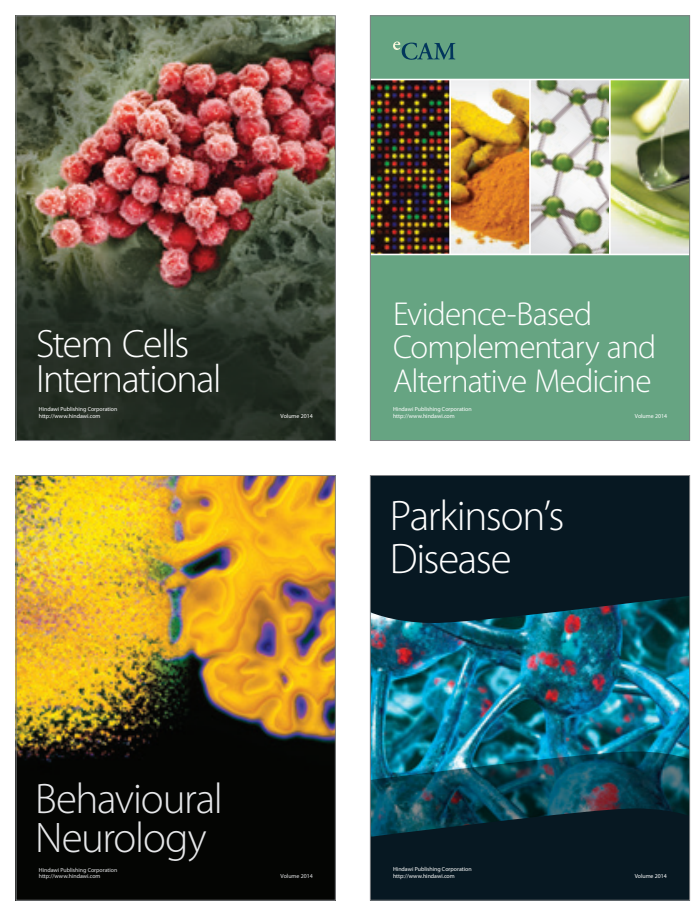

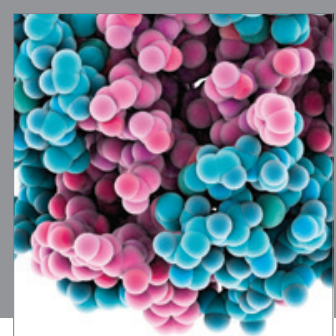

Journal of
Diabetes Research

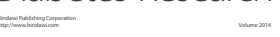

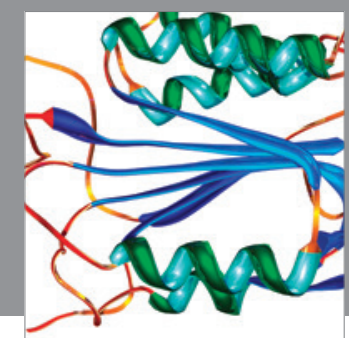

Disease Markers
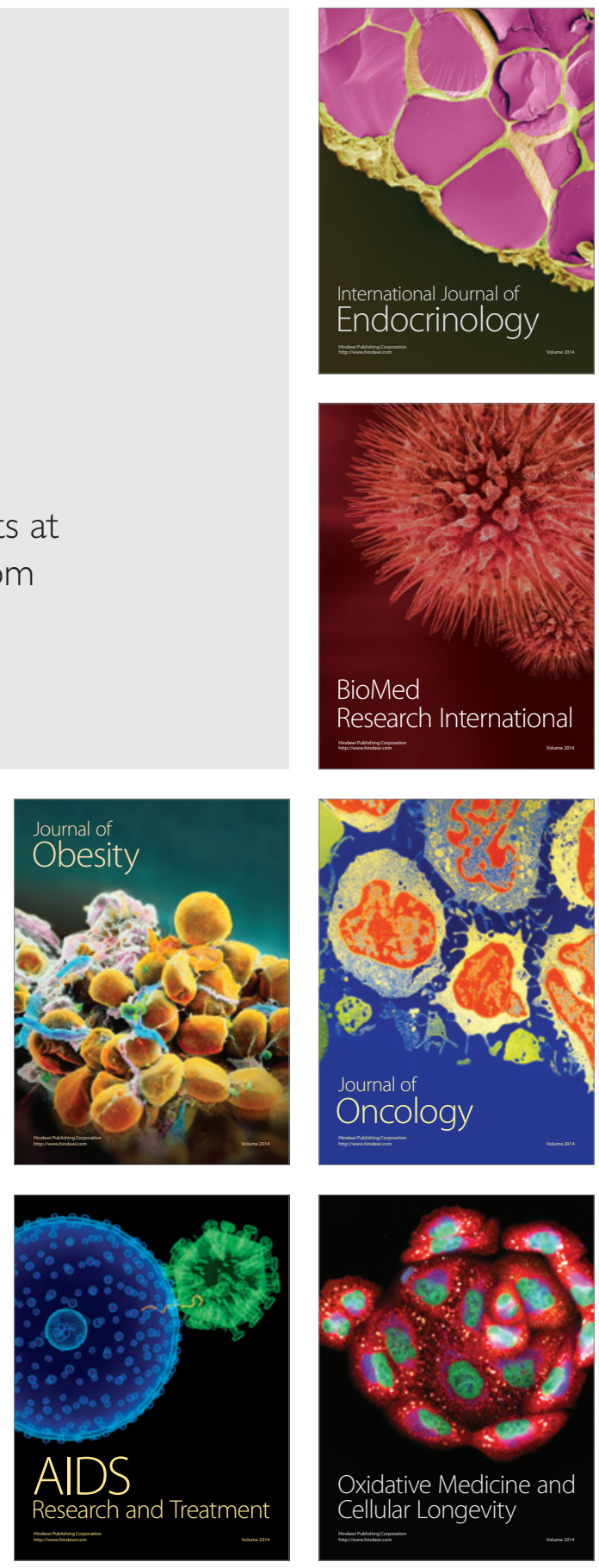